\title{
Pengaruh Kualitas Produk, Word of Mouth, dan Store Image terhadap Keputusan Pembelian: Studi pada Pengunjung Toko Amigo Pedan
}

\author{
Wita Marantika \\ Sarsono \\ Manajemen, Universitas Islam Batik Surakarta, Indonesia \\ Korespondensi penulis: marantika.wita08@gmail.com
}

\begin{abstract}
Marketing is the process of selling goods and services that aims to meet and satisfy customer wants. The purpose of this study is to determine the effects of product quality, word of mouth, and store image on purchasing decisions in Amigo Pedan store, Klaten, Central Java, Indonesia. The population in this study is the visitors of Amigo Pedan with a sample of 91 respondents. The sampling technique used in this study was incidental sampling. Primary data was collected using questionnaires. This study used multiple linear regression analysis. The results of this research showed that product quality, word of mouth, and store image have significant and positive effects on purchasing decisions in the store, simultaneously. But, only the word of mouth has a significant effect on customers 'purchasing decisions in the store, partially.
\end{abstract}

Keywords: Product quality; Word of mouth; Store image; Purchasing decision.

Abstrak. Pemasaran merupakan proses penjualan barang dan jasa yang bertujuan untuk memenuhi dan memuaskan keinginan pelanggan. Tujuan penelitian ini untuk mengetahui pengaruh kualitas produk, word of mouth, dan store image terhadap keputusan pembelian di Toko Amigo Pedan, Klaten, Jawa Tengah, Indonesia. Populasi dalam penelitian ini adalah seluruh pengunjung Toko Amigo Pedan dengan jumlah sampel 91 orang responden. Teknik penentuan sampel menggunakan incidental sampling. Pengambilan data primer dilakukan dengan penyebaran kuesioner. Penelitian ini menggunakan analisis regresi linier berganda. Hasil penelitian menunjukkan bahwa kualitas produk, word of mouth, dan store image berpengaruh signifikan dan positif terhadap keputusan pembelian pengunjung Toko Amigo Pedan secara simultan. Di sisi lain, hanya word of mouth yang memiliki pengaruh signifikan terhadap keputusan pembelian di Toko Amigo Pedan secara parsial.

Kata kunci: Kualitas produk; Word of mouth; Store image; Keputusan pembelian. 


\section{LATAR BELAKANG}

Pesatnya perkembangan zaman di era milenial menimbulkan persaingan ketat di bidang perdagangan. Keunggulan produk yang memiliki daya saing menjadi salah satu dari beberapa faktor penting dalam keputusan pembelian konsumen. Unsur-unsur yang terdapat pada produk, seperti warna, disain, ukuran, packaging, dan lain-lain menjadi faktor yang dipertimbangkan oleh konsumen untuk membelinya (Ernawati, 2019). Beberapa faktor menjadi pertimbangan konsumen dalam proses penentuan produk yang akan dibeli (Fahimah, Fauzi, \& Hidayat, 2015). Salah satu daya tarik konsumen mengambil keputusan pembelian dapat ditentukan oleh kualitas produk yang ditawarkan perusahaan dan kemampuannya memenuhi kebutuhan konsumen. Perusahaan harus mampu menawarkan produk sesuai spesifikasi yang disyaratkan oleh konsumen. Kualitas yang baik dapat menghasilkan kepuasan bagi konsumen dan mempengaruhi loyalitas mereka atas produk yang ditawarkan (Puspita, Yulianto, \& Sunarti, 2016).

Informasi secara word of mouth dapat mendorong keputusan pembelian pada produk tertentu. Penyebaran informasi produk yang dilakukan dari mulut ke mulut menjadi faktor penting untuk memberikan efek kepercayaan pada konsumen. Komunikasi word of mouth menjadi penting, karena sebagian besar penawarannya diperoleh dari pengalaman atau kepercayaan nyata (Basri, Ahmad, Anuar, \& Ismail, 2016). Peningkatan word of mouth dapat menentukan pembelian konsumen (Hasyim, Fauzi, \& Fanani, 2017). Selain itu, store image menjadi salah satu strategi penting bagi perusahaan untuk memasarkan produk yang dapat memberikan kesan tentang ciri khas sebuah toko yang mudah diingat masyarakat. Store image perusahaan seharusnya dapat dipertahankan untuk menjaga konsistensi dalam pemenuhan kebutuhan konsumen sesuai dengan yang mereka inginkan. Membangun hubungan baik dengan konsumen dan kualitas layanan yang baik dapat meningkatkan niat beli konsumen (Erdil, 2015). Semakin tinggi nilai kualitas produk, maka keinginan konsumen untuk membeli juga semakin meningkat (Amron, 2018).

Amigo Group merupakan sebuah perusahan retail modern yang bergerak di bidang fashion dan sepatu yang berkualitas dengan beberapa brand terkenal. Amigo Group telah memiliki beberapa cabang di kota-kota besar, seperti Klaten, Solo, dan Yogyakarta. Toko retail ini memiliki tagline yang cukup dikenal oleh masyarakat luas, yakni "jelas beda, beda jelas." Kepuasan pelanggan menjadi prioritas perusahaan. Untuk mewujudkannya, Amigo Group memberikan produk dan layanan secara khusus dan berupaya memuaskan pelanggan secara maksimal. Berbagai kemudahan diberikan kepada pelanggan oleh Amigo, antara lain: memberikan Amigo Member Card sebagai bentuk apresiasi atas kesetiaan pelanggan dengan memberikan keuntungan tambahan berupa poin maupun kesempatan untuk mengikuti berbagai macam promo menarik; memberikan layanan tambahan kepada pelanggan tanpa dikenakan biaya tambahan, seperti potong celana, gift wrapping, mengemas hantaran pernikahan, dan minuman ringan; serta makanan kecil bagi pengunjung anak-anak yang datang ke toko-toko Amigo Group bersama orang tua mereka.

Di era globalisasi saat ini, fashion telah menjadi bagian dari kehidupan masyarakat. Fashion menjadi bagian yang tidak dapat dilepaskan dari gaya keseharian. Seseorang dapat menunjukkan jati dirinya dengan gaya busana yang dikenakannya. Selain itu, produkproduk yang dipasarkan harus memiliki kualitas sesuai yang diinginkan masyarakat. Perubahan gaya hidup yang mengikuti tren mode akan memberikan penawaran beragam terkait jenis fashion style untuk menunjang penampilan yang sedang tren saat ini. Toko 
ritel fashion menjadi salah satu tempat favorit yang hampir selalu ramai dikunjungi masyarakat untuk mendapatkan fashion style yang mereka inginkan. Perilaku konsumen terkadang tidak dapat diprediksi ketika keinginan membeli suatu produk timbul secara tiba-tiba. Sebenarnya, pada saat itu konsumen tidak merencanakan pembelian produk fashion. Melihat produk yang terpajang (display) dan dikemas sedemikian rupa secara atraktif dapat menimbulkan dorongan atau tindakan konsumen untuk melakukan keputusan pembelian. Dorongan atau tindakan konsumen tersebut dapat berupa keputusan pembelian terhadap produk yang ditawarkan. Dari uraian tersebut, pertanyaan yang muncul dan mendasari penelitian ini adalah apakah kualitas produk, word of mouth, dan store image memiliki pengaruh terhadap keputusan pembelian di Toko Amigo Pedan.

Menurut penelitian Arifa, Hartono dan Robustin (2018), kualitas produk dan word of mouth berpengaruh signifikan terhadap keputusan pembelian konsumen. Di sisi lain, Purwati, Yusrizal, dan Ramadhani (2019) menemukan bahwa kualitas produk dan store image berpengaruh signifikan terhadap keputusan pembelian konsumen sedangkan penelitian Puspita et al. (2016) mengungkapkan bahwa store image berpengaruh signifikan terhadap keputusan pembelian konsumen. Selanjutnya, Nugroho, Suharyono, dan Sunarti (2018) menemukan bahwa word of mouth berpengaruh signifikan terhadap keputusan pembelian konsumen, sedangkan Budiyanto, Kojo, dan Tawas (2016) menyatakan bahwa kualitas produk tidak berpengaruh terhadap keputusan pembelian konsumen, sedangkan Bulele (2016) membuktikan bahwa store image tidak berpengaruh terhadap keputusan pembelian konsumen. Berdasarkan pertanyaan dan kesenjangan penelitian tersebut, penelitian ini bertujuan untuk mengetahui pengaruh kualitas produk, word of mouth, dan store image terhadap keputusan pembelian di Toko Amigo Pedan, baik secara parsial maupun simultan.

\section{KAJIAN TEORITIS}

\section{Pemasaran}

Pemasaran adalah salah satu kegiatan penting dalam dunia usaha ketika perusahaan menciptakan nilai bagi pelanggan dan membangun hubungan yang kuat dengan mereka (Kotler \& Armstrong, 2014). Pemasaran juga diartikan sebagai sebuah proses sosial atau fungsi organisasi dalam kegiatan bisnis yang bertujuan untuk menyalurkan atau mendistribusikan produk dalam rangka memuaskan kebutuhan dan keinginan konsumen. Selain pemahaman mengenai pemasaran, manajemen pemasaran mempunyai peran penting untuk mewujudkan tujuan perusahaan. Tugas manajemen pemasaran adalah melakukan perencanaan tentang bagaimana perusahaan mampu menangkap peluang pasar untuk melakukan pertukaran barang dan jasa dengan konsumen (Purwati et al., 2019).

\section{Keputusan Pembelian}

Arifa et al. (2018) menyebutkan bahwa keputusan pembelian adalah perilaku pembelian yang dilakukan individu untuk menentukan produk yang dipilih guna memperoleh kepuasan pembelian sesuai dengan kebutuhan dan keinginannya. Fahimah et al. (2015) menyatakan bahwa proses penentuan produk yang akan dibeli oleh konsumen berdasarkan pertimbangan alternatif yang sudah ada sebelumnya dan telah dilakukan evaluasi terhadapnya. Marchall, Mananeke, dan Roring (2015) menyatakan proses 
pengintegrasian dan kombinasi pengetahuan untuk mengevaluasi dua perilaku alternatif atau lebih, dan memilih salah satu di antaranya. Suatu pilihan yang ditunjukkan sebagai keinginan berperilaku adalah hasil dari proses pengintegrasian. Menurut Kotler dan Keller (2017:214), keputusan pembelian dipengaruhi oleh beberapa facktor, yaitu: faktor budaya, sosial, pribadi, dan psikologi. Berdasarkan pendapat tersebut, keputusan pembelian dapat dilakukan karena adanya kebutuhan yang dipengaruhi oleh beberapa factor, antara lain sikap orang lain dan faktor situasional. Konsumen akan mempertimbangkan informasi yang berkaitan dengan barang atau jasa yang akan dibeli. Selanjutnya, evaluasi pembeli menentukan apakah ia akan melakukan keputusan pembelian.

\section{Kualitas Produk}

Arifa et al. (2018) mendefinisikan kualitas produk sebagai kesadaran terhadap produk yang memiliki nilai lebih dibandingkan dengan produk pesaing. Ong \& Sugiharto (2013) menyebutkan bahwa kemudahan, daya tahan, fungsi, keberagaman, dan lain-lain merupakan sebagian indikator kualitas produk. Kualitas produk memiliki keterkaitan dengan pengambilan keputusan pembelian oleh konsumen. Spesifikasi kualitas produk yang mampu dipenuhi perusahaan sesuai keinginan konsumen akan memberikan dampak positif bagi perusahaan tersebut. Konsumen akan merasa puas atas produk yang ditawarkan apabila produk tersebut tidak mudah rusak dan mutunya tinggi. Konsumen dapat melakukan pembelian produk sesuai kriteria mereka. Hal ini sejalan dengan penelitian Lotulung, Lapian, dan Moniharapon (2017) menemukan bahwa peningkatan kualitas produk yang semakin baik akan meningkatkan keputusan pembelian oleh konsumen.

Berdasarkan penjelasan tersebut, kualitas produk merupakan salah satu faktor yang mendasari keputusan pembelian konsumen. Jika kualitas produk sesuai keinginan konsumen, hal itu merupakan nilai tambah bagi perusahaan, sehingga kepuasan konsumen dapat tercapai. Dari uraian tersebut, maka hipotesis kesatu yang diajukan dalam penelitian ini adalah:

\section{H1: Terdapat pengaruh Kualitas Produk secara signifikan terhadap Keputusan Pembelian pengunjung Toko Amigo Pedan secara parsial.}

\section{Word of Mouth}

Word of mouth (WOM) menjadi alternatif promosi yang dianggap efektif untuk memperoleh kesadaran konsumen potensial. Wujud WOM adalah informasi lebih tentang suatu produk, kejadian, jasa, tempat, atau karya melalui orang lain (Arifa et al. 2018). Konsumen cenderung lebih mempercayai informasi produk yang didengar dari orang terpercaya, keluarga, atau orang yang sudah berpengalaman terhadap pembelian produk dibandingkan iklan dari toko (Nugroho et al. 2018). Salah satu bentuk promosi yang efektif untuk menawarkan produk kepada masyarakat adalah word of mouth atau komunikasi dari mulut ke mulut. Strategi ini dipandang lebih efektif, karena penyampaian informasi produk oleh seorang konsumen merupakan pengalaman pribadi. Pengalaman konsumsi tersebut sudah pernah dilakukan dalam bentuk tindakan pembelian terhadap produk tersebut. Konsumen yang telah membeli dapat merekomendasikan produk tersebut kepada konsumen yang lain sebagai bentuk referensi atau informasi tambahan yang dapat mempengaruhi keputusan pembelian mereka. 
Penelitian Subandi (2016) menemukan bahwa promosi yang dilakukan melalui WOM memiliki dampak yang signifikan dan efektif memberikan referensi kepada masyarakat, sehingga WOM dapat membantu konsumen lain sebelum melakukan pembelian produk. Merujuk pada penelitian Hasyim et al. (2017), WOM yang dilakukan dengan baik cenderung dapat meningkatkan keputusan pembelian produk. Berdasarkan beberapa hasil penelitian tersebut, WOM merupakan salah satu alternatif strategi promosi bagi perusahaan untuk memasarkan produknya. Konsumen cenderung mempercayai informasi dari pengalaman yang sudah pernah dialami oleh orang lain. Pengaplikasian komunikasi yang baik dan positif dari mulut ke mulut tentang produk yang dibicarakan secara terus menerus akan berpengaruh pada mindset konsumen untuk melakukan pembelian. Dari uraian tersebut, maka hipotesis kedua yang diajukan dalam penelitian ini adalah:

\section{H2: Terdapat pengaruh Word of Mouth secara signifikan terhadap Keputusan Pembelian pengunjung Toko Amigo Pedan secara parsial.}

\section{Store Image}

Sopiah dan Syihabudhin (2008:138), store image dapat dipahami sebagai kepribadian suatu toko yang digambarkan melalui apa pun yang dapat dilihat secara fisik maupun dirasakan oleh konsumen. Possitioning toko pada store image yang diciptakan tidak sama dengan pesaingnya akan dapat mempengaruhi minat pembelian konsumen (Maretha \& Kuncoro, 2011). Store image juga menjadi salah satu alternatif bagi perusahaan untuk menarik perhatian konsumen agar mereka bersedia melakukan pembelian produknya. Promosi dan penyelenggaraan events yang dilakukan sebuah toko dapat memberikan pengaruh pada terjadinya pembelian dan menciptakan citra toko di benak konsumen sesuai yang diinginkan pemasar. Dampak dari store image yang baik akan mempengaruhi persepsi konsumen dan menggerakkannya untuk melakukan pembelian produk. Maretha dan Kuncoro (2011) menemukan bahwa store image atau citra positif yang dimiliki toko mempunyai pengaruh signifikan terhadap keputusan pembelian konsumen.

Berdasarkan hal-hal tersebut, store image merupakan identitas diri sebuah toko yang dapat mendiferensiasikannya dari para kompetitornya. Store image yang sudah melekat di benak konsumen dapat menumbuhkan kesadaran atas perbedaan di antara merek-merek toko lainnya. Ketika masyarakat mendengar atau melihat produk tertentu, maka mindset dan presepsi mereka akan langsung tertuju pada toko tersebut. Dari uraian tersebut, maka hipotesis ketiga yang diajukan dalam penelitian ini adalah:

\section{H3: Terdapat pengaruh Store Image secara signifikan terhadap Keputusan Pem- belian pengunjung Toko Amigo Pedan secara parsial.}

Secara keseluruhan, penelitian ini juga mengajukan hipotesis keempat, yaitu:

\section{H4: Terdapat pengaruh Kualitas Produk, Word of Mouth, dan Store Image seca- ra signifikan terhadap Keputusan Pembelian pengunjung Toko Amigo Pedan secara simultan.}

Model penelitian ini ditunjukkan pada Gambar 1 yang menggambarkan keterkaitan antara variabel independen, yaitu kualitas produk (X1), word of mouth (X2), dan 
store image (X3), dan variabel dependen, yaitu keputusan pembelian (Y). Keterkaitan antarvariabel ditunjukkan pada hipotesis yang diajukan dalam penelitian ini, yaitu pengaruh variabel bebas X1, X2, dan X3 terhadap variabel tergantung (Y), baik secara parsial maupun simultan, sedangkan Tabel 1 menunjukkan indikator-indikator yang digunakan untuk mengukur setiap variabel yang digunakan dalam penelitian ini.

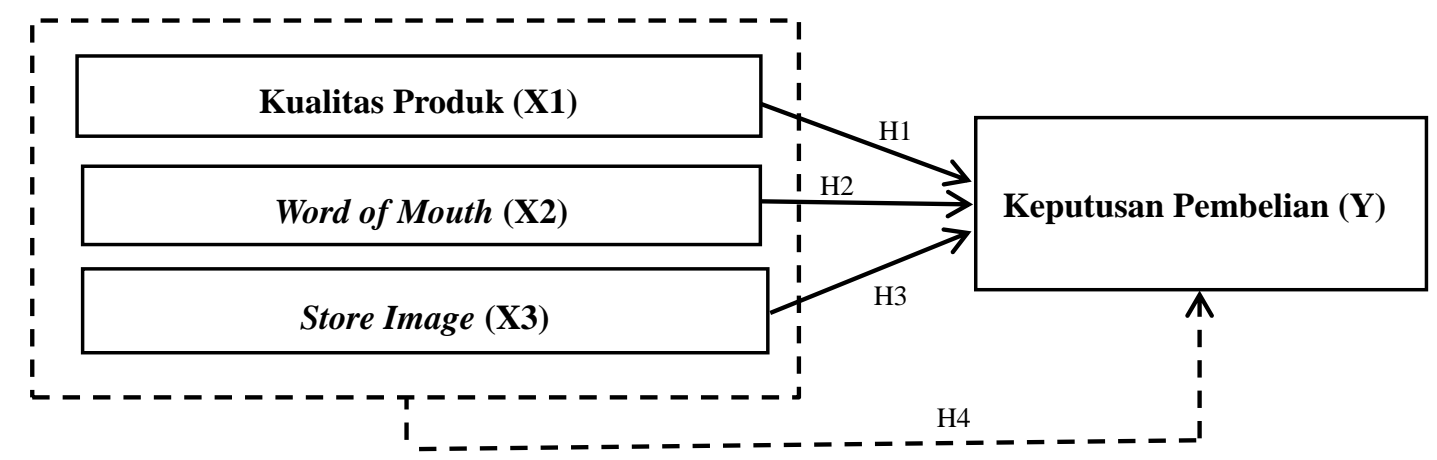

\section{Gambar 1. Model Penelitian}

Keterangan:

$\mathrm{Hn}=$ hipotesis ke-n; Xn = variabel independen ke-n; Y = variabel dependen.

$\longrightarrow$ Pengaruh secara parsial $(\mathrm{H} 1, \mathrm{H} 2$, dan $\mathrm{H} 3)$.

Tabel 1. Pengukuran Variabel Penelitian

\begin{tabular}{ll}
\hline Variabel & \multicolumn{1}{c}{ Indikator \& Referensi } \\
\hline & (1) Pengenalan kebutuhan; (2) Pencarian informasi; (3) Evaluasi \\
& alternatif; (4) Keputusan pembelian; dan (5) Perilaku setelah pembe- \\
Keputusan Pembelian & lian.
\end{tabular}

(Kusumawati, Sriwidodo, \& Sumaryanto, 2016)

(1) Performance (kinerja); (2) Durabiity (daya tahan); (3) Conformance to specifications (Kesesuaian dengan spesifikasi); (4) Features (Fitur); (5) Reliability (Reliabilitas); (6) Aesthetics (Estetika); (7)

Kualitas Produk Perceived quality (Kualitas yang dipersepsikan); dan (8) Serviceability (Kemampuan layanan yaitu kecepatan dan kemudahan).

(Purwati, Yusrizal, \& Ramadhani, 2019)

(1) Membicarakan; (2) Membicarakan kenyamanan produk kepada orang lain; (3) Merekomendasikan; (4) Bersedia membantu orang

Word Of Mouth lain memilih produk yang akan dibeli; dan (5) Mendorong.

(Kusumawati, Sriwidodo, \& Sumaryanto, 2016)

(1) Reputasi took; (2) Layanan; (3) Kelengkapan barang; dan (4)

Store Image Memiliki physical facilities yang baik.

(Purwati, Yusrizal, \& Ramadhani, 2019)

Sumber: Referensi terkait. 


\section{METODE PENELITIAN}

Penelitian ini menggunakan pendekatan kuantitatif. Analisis data dalam penelitian ini menggunakan analisis statistik untuk menjelaskan obyek penelitian. Penelitian ini berlokasi di Kecamatan Pedan, Kabupaten Klaten, Provinsi Jawa Tengah. Survei pengumpulan data primer dilaksanakan selama empat bulan, yaitu mulai bulan Oktober 2019 hingga Januari 2020. Populasi penelitian ini adalah semua pengunjung Toko Amigo Pedan. Teknik penentuan sampel dalam penelitian ini menggunakan incidental sampling, yaitu teknik pengambilan sampel berdasarkan faktor insidental atau secara kebetulan, yakni siapa saja yang secara tidak sengaja bertemu dengan peneliti dan memenuhi syarat sebagai sampel dalam penelitian ini (Sugiyono, 2016:85). Penyebaran kuesioner dilakukan terhadap 111 responden, yang terdiri atas 20 responden digunakan sebagai sampel uji validitas dan reliabilitas, sedangkan 91 responden digunakan untuk pengujian hipotesis. Jumlah 91 responden merupakan data rata-rata jumlah pengunjung Toko Amigo Pedan per bulan.

Variabel yang diteliti dalam penelitian ini, yaitu variabel independen (independent variable) yang terdiri atas kualitas produk, word of mouth, dan store image, sedangkan variabel dependen (dependent variable) adalah keputusan pembelian pengunjung Toko Amigo Pedan. Data yang diperlukan dalam penelitian ini adalah data primer yang berasal dari jawaban responden atas kuesioner dan data sekunder yang berasal dari berbagai literatur yang meliputi buku, jurnal ilmiah, maupun laporan dari instansi terkait obyek penelitian. Metode pengumpulan data primer melalui survei dengan kuesioner, sedangkan pengukuran variabel menggunakan skala Likert (Sugiyono, 2016:93). Jawaban pada setiap butir pernyataan disediakan lima alternatif jawaban yang diberikan bobot (skor) untuk setiap butirnya, yaitu Sangat Tidak Setuju (STS) skor 1, Tidak Setuju (TS) skor 2, Netral (N) skor 3, Setuju (S) skor 4, dan Sangat Setuju (SS) skor 5.

Untuk memastikan instrumen yang digunakan dalam penelitian ini memenuhi kriteria yang andal dan reliabel, data primer yang diperoleh dari responden dilakukan pengujian validitas dan reliabilitas instrumen penelitian. Uji validitas merupakan sebuah alat ukur yang digunakan untuk mengukur sah atau tidaknya instrumen penelitian (Ghozali, 2006:45). Dasar pengambilan keputusan hasil uji validitas adalah:

a) Butir pertanyaan atau pernyataan di dalam kuesioner dapat dikatakan valid, apabila r-hitung > r-tabel atau t-hitung $>$ t-tabel atau Sig < alpha $(\alpha)$.

b) Butir pertanyaan atau pernyataan di dalam kuesioner dapat dikatakan tidak valid apabila r-hitung < r-tabel atau t-hitung < t-tabel atau Sig > alpha $(\alpha)$.

Uji reliabilitas instrumen penelitian dilakukan untuk mengukur reliabilitas indikator konstrak. Instrumen kuesioner dikatakan reliabel atau andal, apabila jawaban responden terhadap pernyataan bersifat konsisten atau stabil dari waktu ke waktu (Ghozali, 2006:41). Pengujian reliabilitas instrumen penelitian ini menggunakan metode Cronbach's Alpha. Suatu konstrak dikatakan reliabel apabila nilai Cronbach's alpha lebih besar daripada 0,60 .

\section{HASIL DAN PEMBAHASAN}

\section{Diskripsi Responden}

Berdasarkan data yang terkumpul dari 91 responden, pertanyaan diskripsi responden meliputi jenis kelamin, usia, pekerjaan, dan tingkat pendapatan. Tabel 2 menunjuk- 
kan data diskripsi jenis kelamin responden. Responden perempuan mendominasi pembelian produk fashion di Toko Amigo Pedan, yaitu berjumlah 82 orang $(90,11 \%)$, sedangkan responden laki-laki sebanyak 9 orang $(9,89 \%)$. Pada umumnya, perempuan lebih memperhatikan dan sensitif dengan produk pakaian yang dikenakannya. Pembelian produk fashion dianggap menjadi kebutuhan vital bagi kaum perempuan. Selain itu, produk fashion menjadi salah satu penunjang penting bagi penampilan perempuan untuk mendapatkan perhatian yang semakin tinggi dari orang lain. Sebuah pepatah Jawa mengungkapkan "ajining raga ana ing busana." Pepatah tersebut memiliki makna bahwa kepribadian seseorang dapat dilihat dari busana yang dikenakannya.

Tabel 2. Klasifikasi Responden Berdasarkan Jenis Kelamin

\begin{tabular}{cccc}
\hline No & Jenis Kelamin & Frekuensi & Presentase (\%) \\
\hline 1 & Laki-laki & 9 & 9,89 \\
\hline 2 & Perempuan & 82 & 90,11 \\
\hline & Jumlah & $\mathbf{9 1}$ & $\mathbf{1 0 0 , 0 0}$ \\
\hline
\end{tabular}

Sumber: Data primer diolah (2020).

Tabel 3 menunjukkan bahwa responden dengan rentang usia 17-25 tahun sebanyak 23 orang $(25,27 \%)$, sedangkan rentang usia 26-35 tahun sebanyak 47 orang $(51,65 \%)$, dan rentang usia 36-45 tahun sebanyak 18 orang $(19,78 \%)$, serta yang berusia di atas 45 tahun sebanyak 3 orang (3,30\%). Dari gambaran tersebut, pengunjung Toko Amigo Pedan didominasi oleh mereka yang berusia antara 26-35 tahun. Gambaran tersebut menunjukkan bahwa konsumen dalam rentang usia 26-35 tahun relatif masih lebih memperhatikan kebutuhan fashion. Dari diskripsi jenis kelamin dan usia, mayoritas ibu-ibu berusia muda cenderung lebih peka memikirkan kebutuhan fashion untuk dirinya maupun keluarganya.

Tabel 3. Klasifikasi Responden Berdasarkan Usia

\begin{tabular}{cccc}
\hline No & Usia & Frekuensi & Presentase (\%) \\
\hline 1 & $17-25$ tahun & 23 & 25,27 \\
\hline 2 & $26-35$ tahun & 47 & 51,65 \\
\hline 3 & $36-45$ tahun & 18 & 19,78 \\
\hline 4 & $>45$ tahun & 3 & 3,30 \\
\hline & Jumlah & $\mathbf{9 1}$ & $\mathbf{1 0 0 , 0 0}$ \\
\hline
\end{tabular}

Sumber: Data primer diolah (2020).

Berdasarkan Tabel 4, responden sebagai pengunjung Toko Amigo Pedan berprofesi atau memiliki pekerjaan cukup variatif. Responden yang berprofesi sebagai aparat sipil negara (ASN) sebanyak 2 orang $(2,20 \%)$, karyawan swasta 40 orang $(43,96 \%)$, wiraswasta 20 orang $(21,98 \%)$, mahasiswa/pelajar 4 orang $(4,40 \%)$, serta profesi lainnya sebanyak 25 orang $(27,47 \%)$. Mayoritas responden berprofesi sebagai karyawan swasta.

Tabel 5 menunjukkan bahwa pengunjung Toko Amigo Pedan yang memiliki pendapatan kurang dari Rp1.000.000 sebanyak 37 orang (40,66\%), berpendapatan antara Rp1.000.000-Rp3.000.000 sebanyak 41 orang (45,05\%), pada kisaran Rp3.000.000Rp5.000.000 sebanyak 5 orang (5,49\%), dan berpendapatan lebih dari Rp5.000.000 
sebanyak 8 orang $(8,79 \%)$. Dari data tersebut, sebagian besar pengunjung di Toko Amigo Pedan adalah konsumen yang berpendapatan antara Rp1.000.000-Rp3.000.000. Pendapatan tersebut merupakan pendapatan rata-rata responden per bulan. Namun, pembeli di Toko Amigo Pedan terdiri atas mereka yang berasal dari berbagai kalangan dan tingkat pendapatan.

Tabel 4. Klasifikasi Responden Berdasarkan Pekerjaan

\begin{tabular}{clcc}
\hline No & Pekerjaan & Frekuensi & Presentase (\%) \\
\hline 1 & Aparat Sipil Negara (ASN) & 2 & 2,20 \\
\hline 2 & Karyawan Swasta & 40 & 43,96 \\
\hline 3 & Wiraswasta & 20 & 21,98 \\
\hline 4 & Mahasiswa/Pelajar & 4 & 4,40 \\
\hline 5 & Lainnya & 25 & 27,47 \\
\hline Jumlah & $\mathbf{9 1}$ & $\mathbf{1 0 0 , 0 0}$ \\
\hline
\end{tabular}

Sumber: Data primer diolah (2020).

Tabel 5. Klasifikasi Responden Berdasarkan Pendapatan

\begin{tabular}{cccc}
\hline No & Pendapatan (Rupiah) & Frekuensi & Presentase (\%) \\
\hline 1 & $<$ Rp1.000.000 & 37 & 40,66 \\
\hline 2 & Rp1.000.000 - Rp3.000.000 & 41 & 45,05 \\
\hline 3 & Rp3.000.000-Rp5.000.000 & 5 & 5,49 \\
\hline 4 & $>$ Rp5.000.000 & 8 & 8,79 \\
\hline & Jumlah & $\mathbf{9 1}$ & $\mathbf{1 0 0 , 0 0}$ \\
\hline
\end{tabular}

Sumber: Data primer diolah (2020).

\section{Uji Validitas dan Reliabilitas}

Uji validitas instrumen penelitian ini menunjukkan bahwa nilai r-hitung masingmasing variabel lebih besar dari r-tabel $(0,444)$, sehingga hasil tersebut menunjukkan bahwa instrumen penelitian ini dapat dinyatakan valid. Uji reliabilitas instrumen penelitian ini mengukur konsistensi instrumen penelitian yang menunjukkan bahwa nilai Cronbach's alpha masing-masing konstrak lebih besar dari 0,60, sehingga instrumen dapat dikatakan reliabel sebagai alat pengukuran yang sah.

\section{Analisis Data}

\section{a. Analisis Regresi Linier Berganda}

Analisis data dalam penelitian ini menggunakan analisis regresi linier berganda dengan bantuan aplikasi SPSS versi 21 untuk mengolah data. Hasil uji regresi linier berganda mendapatkan persamaan regresi [1] sebagai berikut:

$$
\mathrm{Y}=3,967+0,136 \times 1+0,388 \times 2+0,151 X 3+e
$$

Keterangan:

$\mathrm{Y}=$ Keputusan Pembelian

$\mathrm{X} 1$ = Variabel Kualitas Produk

$\mathrm{X} 2$ = Variabel Word of Mouth

$\mathrm{X} 3$ = Variabel Store Image

$\mathrm{e} \quad=$ Error terms.

Nilai konstanta pada persamaan [1] tersebut menunjukkan bahwa variabel keputusan pembelian (Y) mencapai nilai 3,967, apabila variabel kualitas produk (X1), word 
of mouth (X2), dan store image (X3) masing-masing bernilai 0. Nilai koefisien regresi variabel independen menunjukkan tingkat perubahan pada variabel dependen keputusan pembelian (Y) akibat perubahan variabel independennya. Koefisien regresi variabel kualitas produk (X1) menunjukkan angka 0,136 , word of mouth (X2) 0,388, dan store image (X3) adalah 0,151 .

\section{b. Uji Koefisien Determinasi $\left(\mathbf{R}^{2}\right)$}

Hasil analisis data menggunakan aplikasi SPSS versi 21 menunjukkan bahwa nilai koefisien determinasi sebesar 0,547 atau $54,7 \%$ (Tabel 6). Hasil tersebut membuktikan bahwa kualitas produk (X1), word of mouth (X2), dan store image (X3) mampu menjelaskan variasi pada variabel keputusan pembelian (Y) sebesar 54,7\%, sedangkan sisanya sebesar 45,3\% variasi keputusan pembelian dijelaskan oleh faktor-faktor lain yang tidak digunakan dalam model penelitian ini.

Tabel 6. Koefisien Determinasi $\left(\mathbf{R}^{2}\right)$

\begin{tabular}{ccl}
\hline Model & $\boldsymbol{R}$-Square & \multicolumn{1}{c}{ Keterangan } \\
\hline 1 & 0,547 & $\begin{array}{l}\text { Kemampuan variabel independen menjelaskan } \\
\text { variasi pada variabel dependen }(54,7 \%) .\end{array}$ \\
\hline
\end{tabular}

Sumber: Data Primer diolah (2020).

\section{c. Uji t (Pengaruh secara Parsial)}

Tabel 7 menunjukkan hasil olah data berdasarkan uji t yang menunjukkan pengaruh secara parsial variabel independen terhadap variabel dependen. Berdasarkan hasil olah data menggunakan aplikasi SPSS 21, hipotesis pertama (H1) ditolak yang berarti bahwa variabel kualitas produk (X1) tidak memberikan pengaruh signifikan secara parsial terhadap keputusan pembelian (Y) di Toko Amigo Pedan. Hasil tersebut ditunjukkan dengan nilai $t_{\text {hitung }}$ sebesar 1,815 lebih kecil daripada $t_{\text {tabel }}$ 1,987. Di sisi lain, hipotesis kedua $(\mathrm{H} 2)$ dalam penelitian ini dapat diterima berdasarkan nilai $t_{\text {hitung }}$ sebesar 5,544 yang lebih besar daripada $t_{\text {tabel }} 1,987$, sehingga variabel word of mouth (X2) dapat dikatakan memberikan pengaruh signifikan secara parsial terhadap keputusan pembelian (Y) di Toko Amigo Pedan. Selanjutnya, variabel store image (X3) juga terbukti tidak memberikan pengaruh secara parsial terhadap keputusan pembelian (Y) di Toko Amigo Pedan berdasarkan nilai $t_{\text {hitung }}$ sebesar 1,825 yang lebih kecil daripada $t_{\text {tabel }} 1,987$.

Tabel 7. Hasil Uji t (Pengaruh Parsial)

\begin{tabular}{lccccc}
\hline \multicolumn{1}{c}{ Variabel } & $\mathbf{t}_{\text {hitung }}$ & $\mathbf{t}_{\text {tabel }}$ & Sig. & Std & Hipotesis \\
\hline Kualitas Produk (X1) & 1,815 & 1,987 & 0,073 & $<0,05$ & H1 ditolak \\
\hline Word of Mouth $(\mathrm{X} 2)$ & 5,544 & 1,987 & 0,000 & $<0,05$ & H2 diterima \\
\hline Store Image $(\mathrm{X} 3)$ & 1,825 & 1,987 & 0,071 & $<0,05$ & H3 ditolak \\
\hline
\end{tabular}

Keterangan: Std $=$ Standar acuan penerimaan hipotesis.

Sumber: Data Primer diolah (2020).

\section{d. Uji F (Pengaruh secara Simultan)}

Berdasarkan data penelitian yang diolah menggunakan aplikasi SPSS 21, nilai

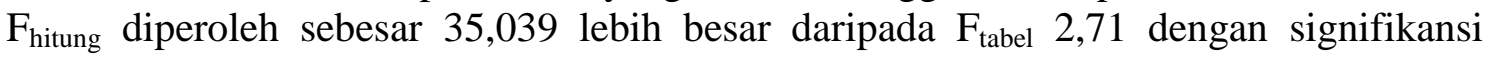


0,000 atau kurang dari 0,05 (Tabel 8). Dari hasil tersebut, maka variabel kualitas produk (X1), word of mouth (X2), dan store image (X3) secara simultan dan signifikan mempengaruhi variabel keputusan pembelian (Y) di Toko Amigo Pedan.

Tabel 8. Hasil Uji F (Pengaruh Simultan)

\begin{tabular}{ccccc}
\hline Model & F $_{\text {hitung }}$ & F $_{\text {tabel }}$ & Sig. & Std \\
\hline 1 & 35,039 & 2,71 & 0,000 & $<0,05$ \\
\hline
\end{tabular}

Keterangan: Std = Standar acuan penerimaan hipotesis.

Sumber: Data Primer diolah (2020).

\section{Pembahasan}

\section{Pengaruh Kualitas Produk terhadap Keputusan Pembelian di Toko Amigo Pedan}

Penolakan terhadap $\mathrm{H} 1$ berdasarkan hasil uji t membuktikan bahwa variabel kualitas produk tidak berpengaruh secara parsial terhadap keputusan pembelian produk di Toko Amigo Pedan. Hal tersebut menjelaskan bahwa keputusan pembelian produk fashion oleh konsumen tidak banyak dipengaruhi kualitas produk yang ditawarkan oleh Toko Amigo Pedan. Spesifikasi kualitas produk yang diinginkan oleh konsu-men satu dengan yang lain dapat berbeda sesuai selera dan preferensi mereka. Apabila kualitas produk yang ada tidak sesuai ekspektasi konsumen, maka mereka pun dapat mengurungkan niat untuk membelinya. Hasil ini mendukung penelitian oleh Budiyanto et al. (2016) yang menyatakan bahwa tidak ada keterkaitan antara variabel kualitas produk dengan keputusan pembelian konsumen.

\section{Pengaruh Word of Mouth terhadap Keputusan Pembelian di Toko Amigo Pedan}

Berbeda dengan variabel kualitas produk yang tidak berpengaruh, hasil uji t dalam penelitian ini membuktikan bahwa variabel word of mouth berpengaruh signifikan terhadap keputusan pembelian produk fashion di Toko Amigo Pedan. Hasil tersebut memberikan pemahaman bahwa konsumen melakukan pembelian produk fashion di Toko Amigo Pedan sangat dipengaruhi peran word of mouth. Semakin banyak informasi positif yang beredar di masyarakat tentang produk yang ditawarkan Toko Amigo Pedan, maka pembelian konsumen akan meningkat secara signifikan. Ada-nya komunikasi informal tersebut dapat membuka ruang interaksi antarindividu untuk bertukar informasi dan pengalaman mereka tentang pembelian produk fashion di Toko Amigo Pedan, sehingga informasi positif yang beredar sangat mempeng-aruhi perilaku konsumen lain untuk melakukan pembelian pula di toko yang sama. Hasil ini sejalan dengan penelitian Subandi (2016) dan Nugroho et al. (2018) yang menyatakan adanya pengaruh signifikan word of mouth terhadap keputusan pembe-lian produk konsumen.

\section{Pengaruh Store Image terhadap Keputusan Pembelian di Toko Amigo Pedan}

Hasil uji t pada variabel store image membuktikan tidak adanya pengaruh yang sig-nifikan terhadap keputusan pembelian produk di Toko Amigo Pedan. Hasil tersebut menunjukkan bahwa store image atau citra toko yang dimiliki oleh Toko Amigo Pedan tidak terlalu berpengaruh pada keputusan konsumen membeli produknya. Ketika memutuskan untuk membeli produk, konsumen tidak banyak dipengaruhi oleh citra Toko Amigo Pedan. Konsumen cenderung melakukan pembelian produk dengan cara 
mencari produk yang sesuai dengan kebutuhan dan spesifikasi produk yang mereka inginkan. Hasil penelitian ini sejalan dengan penelitian Bulele (2016) yang menyatakan bahwa citra toko (store image) tidak menentukan keputusan pembelian konsumen.

\section{KESIMPULAN DAN SARAN}

\section{Kesimpulan}

Hasil penelitian ini membuktikan bahwa variabel kualitas produk, word of mouth, dan store image memiliki pengaruh positif dan signifikan secara simultan terhadap keputusan pembelian produk fashion di Toko Amigo Pedan. Namun, variabel kualitas produk dan store image terbukti tidak berpengaruh secara parsial terhadap keputusan pembeliannya. Sebaliknya, variabel word of mouth berpengaruh signifikan secara parsial terhadap keputusan pembelian produk di Toko Amigo Pedan.

\section{Saran}

Temuan dalam penelitian ini menunjukkan bahwa faktor word of mouth merupakan variabel yang sangat menentukan keputusan pembelian konsumen di Toko Amigo Pedan. Toko Amigo Pedan dapat meningkatkan layanan kepada konsumen atau pengunjung tokonya untuk memberikan kesan positif dan kepuasan bagi mereka. Kesan dan kepuasan tersebut dapat menjadi materi promosi penting yang beredar melalui word of mouth. Upaya lainnya adalah memperbanyak promosi yang tidak hanya dilakukan secara offline store saja, tetapi ada pula promosi yang dilakukan melalui media sosial dengan memanfaatkan proses viral marketing agar memberikan dorongan lebih besar kepada konsumen untuk melakukan pembelian produknya. Penelitian di masa mendatang perlu mempertimbangkan pengembangan lebih lanjut dengan memasukkan faktorfaktor lain yang dipandang relevan, seperti gaya hidup, electronic word of mouth (ewom), kepercayaan merek, persepsi produk, store atmosphere, faktor psikologis, dan sebagainya.

\section{DAFTAR REFERENSI}

Amron, A. (2018). Effects of Product Quality, Price, and Brand Image on the Buying Decision of City Car Product. Archives of Business Research, 6(4), 1-8. https:// doi.org/10.14738/abr.64.4374.

Arifa, N., Hartono, H. \& Robustin, T. P. (2018). Pengaruh Kualitas Produk dan Harga serta Word of Mouth terhadap Keputusan Pembelian Kosmetik Wardah (Studi Kasus Mahasiswi STIE Widya Gama Lumajang). Jurnal Riset Manajemen, 1(1), $54-63$.

Basri, N. A. H., Ahmad, R., Anuar, F. I., \& Ismail, K. A. (2016). Effect of Word of Mouth Communication on Consumer Purchase Decision: Malay Upscale Restaurant. Procedia - Social and Behavioral Sciences, 222, 324-331. https://doi.org/ 10.1016/j.sbspro.2016.05.175.

Budiyanto, T., Kojo, C., \& Tawas, H. N. (2016). Strategi Promosi, Kualitas Produk, dan Desain terhadap Keputusan Pembelian dan Minat Mereferensikan Rumah pada Puri Camar Liwas PT Camar Sapta Ganda. Jurnal Berkala Ilmiah Efisiensi, 16 (04), 488-500. 
Bulele, E. Y. (2016). Analisis Pengaruh Citra Toko, Kualitas Pelayanan, dan Ketersediaan Produk terhadap Keputusan Pembelian di Toko Buku Gramedia Manado. Jurnal Berkala Ilmiah Efisiensi, 16(3), 258-269.

Erdil, T. S. (2015). Effects of Customer Brand Perceptions on Store Image and Purchase Intention: An Application in Apparel Clothing. Procedia - Social and Behavioral Sciences, 207, 196-205. https://doi.org/10.1016/j.sbspro.2015.10.088.

Ernawati, D. (2019). Pengaruh Kualitas Produk, Inovasi Produk dan Promosi terhadap Keputusan Pembelian Produk Hi Jack Sandals Bandung. JWM (Jurnal Wawasan Manajemen), 7(1), 17-32. https://doi.org/10.20527/jwm.v7i1.173.

Fahimah, F., Fauzi DH., A., \& Hidayat, K. (2015). Pengaruh Store Atmosphere (Suasana Toko) terhadap Keputusan Pembelian (Survei pada Pengunjung di Madam Wang Secret Garden Cafe Malang). Jurnal Administrasi Bisnis (JAB), 28(2), 110.

Ghozali, Imam. (2006). Aplikasi Analisis Multivariate dengan Program SPSS. Semarang: Badan Penerbit Universitas Diponegoro.

Hasyim, M. A., Fauzi, A., \& Fanani, D. (2017). Pengaruh Citra Merek terhadap Word of Mouth dan Keputusan Pembelian (Survei pada Mahasiswa Fakultas Ilmu Administrasi Universitas Brawijaya Jurusan Administrasi Bisnis Angkatan 2014/2015-2015/2016 Pembeli Handphone Samsung Galaxy). Jurnal Administrasi Bisnis (JAB), 43(1), 148-156.

Kotler, P., \& Armstrong, G. (2014). Principle of Marketing. 15th Edition. New Jersey: Pearson Prentice-Hall (Ed.). https://doi.org/10.1016/j.neuroimage.2008.10.043. Automated

Kotler, P., \& Keller, L. (2017). Manajemen Pemasaran. Edisi 12, Jilid 1. Jakarta: PT Indeks.

Kusumawati, M. S., Sriwidodo, U., \& Sumaryanto, S. (2016). Pengaruh Brand Image terhadap Keputusan Pembelian Shopie Paris dengan Word of Mouth Positif sebagai Variabel Moderasi (Survei pada Mahasiswi Fakultas Ekonomi Universitas Slamet Riyadi Surakarta). Jurnal Ekonomi dan Kewirausahaan, 16(2), 216-225.

Lotulung, S. C., Lapian, J., \& Moniharapon, S. (2015). Pengaruh Kualitas Produk, Harga, dan WOM (Word of Mouth) terhadap Keputusan Pembelian Handphone Evercoss pada CV Tristar Jaya Globalindo Manado. Jurnal EMBA, 3(3), 817-826.

Marchall, M., Mananeke, L., \& Roring, F. (2015). Pengaruh Brand Equity, Store Atmosphere dan Sikap Konsumen terhadap Keputusan Pembelian Pakaian Fashionable pada 3 Second Manado Town Square. Jurnal Riset Ekonomi, Manajemen, Bisnis dan Akuntansi, 3(1), 1002-1012. https://doi.org/10.35794/ emba.v3i1.7805.

Maretha, V., \& Kuncoro, E. A. (2011). Pengaruh Store Atmosphere dan Store Image terhadap Keputusan Pembelian Konsumen pada Toko Buku Gramedia Pondok Indah. Binus Business Review, 2(2), 979-991. https://doi.org/10.1002/uog.7568.

Nugroho, D. W., Suharyono, S. \& Sunarti, S. (2018). Pengaruh Atribut Produk dan Word of Mouth terhadap Keputusan Pembelian. Jurnal Administrasi Bisnis (JAB), $55(1), 125-131$.

Ong, I. A., \& Sugiharto, S. (2013). Analisa Pengaruh Strategi Diferensiasi, Citra Merek, Kualitas Produk dan Harga terhadap Keputusan Pembelian Pelanggan di Cincau Station Surabaya. Jurnal Manajemen Pemasaran, 1(2), 1-11. 
Purwati, A. A., Yusrizal, Y. \& Ramadhani, I. C. (2019). Pengaruh Life Style, Kualitas Produk dan Store Image terhadap Keputusan Pembelian. Journal of Management and Bussines (JOMB), 1(1), 22-36. https://doi.org/10.1017/CBO9781107415324. 004.

Puspita, D. L., Yulianto, E., \& Sunarti, S. (2016). Pengaruh Kualitas Produk dan Word Of Mouth terhadap Keputusan Pembelian (Survei Kepada Konsumen Charles \& Keith di Tunjungan Plaza Surabaya). Jurnal Administrasi Bisnis, 34(1), 79-85.

Sopiah, S. \& Syihabudhin, S. (2008). Manajemen Bisnis Ritel. Yogyakarta: Penerbit Andi.

Subandi, T. (2016). Pengaruh Promosi Word of Mouth dan Preferensi Merek terhadap Keputusan Pembelian. Performa: Jurnal Manajemen dan Start-Up Bisnis, 1(5), 584-593.

Sugiyono, S. (2016). Metode Penelitian Kuantitatif, Kualitatif dan R\&D. Bandung: Alfabeta. 